\title{
The Dawning of a Right
}

\section{Science and the Universal Declaration of Human Rights (1941-1948)}

\author{
Mikel Mancisidor
}

\subsection{INTRODUCTION}

The United Nations (UN) Committee on Economic, Social and Cultural Rights has recently adopted General Comment No. 25 on Science and Economic, Social and Cultural Rights (E/C.12/GC/25), a process in which the author of the present chapter has been intimately involved for five years.

This General Comment, which has normative implications for 170 countries, is an interpretation of the obligations contained in the UN International Covenant on Economic, Social and Cultural Rights (ICESCR) of 1966, which came into effect in 1976. It is also an important step on a long journey that began at the dawn of the Universal Declaration of Human Rights and has not yet finished.

This chapter reviews the origins of that story. To do so, it charts the background from President Franklin D. Roosevelt's famous Four Freedoms speech, delivered in January 1941, to the adoption of the Universal Declaration of Human Rights at the Palais Chaillot in Paris on December 10, 1948, with many steps in between and beyond.

A careful reading of the background and the historical context of the Universal Declaration, supplemented by a study of the travaux préparatoires, will reveal to us that many of the debates, dilemmas, and challenges that we face today were already known in an inchoate form and discussed by our predecessors. Absorbing the lessons of those debates and reflecting on their ideas is not only to pay due homage, but also to undertake an exercise of extraordinary relevance and practicality.

\subsection{THE HISTORICAL CONTEXT AND BACKGROUND}

The Right to Science, ${ }^{1}$ as we will refer to it in this chapter, was recognized in the 1948 Universal Declaration of Human Rights ("the Declaration") as follows:

This denomination is the source of some conflict and is not shared by all scholars in the field. Still, due to its general nature, it will help us to start. We will make the terminology more precise during the course of this chapter. 
27 (1) Everyone has the right freely to participate in the cultural life of the community, to enjoy the arts and to share in scientific advancement and its benefits.

Having read article 27, we may refer to the travaux préparatoires ${ }^{2}$ of the Declaration to discern why its drafters chose those precise words and what they thereby intended to say and leave unsaid. ${ }^{3}$ At first sight, this may seem like a question with a short, straightforward answer. On reflection, however, it is clear that further inquiry is necessary to fully grasp the drafters' intentions.

To fulfil this goal, we must go back in history to January 1941. Eleven months prior to the United States' entry into World War II, President Roosevelt made reference, in his famous "Four Freedoms" speech, to the "enjoyment of the fruits of scientific progress" in a context which allows us to consider it a direct precedent of the Right to Science. The speech is widely recognized as one of the main intellectual precursors of the post-war international system and as one of the foundations of the Universal Declaration. Roosevelt's reference here to science is not secondary or circumstantial. Science is given center stage as President Roosevelt places it amongst the six "basic things" of a "healthy and strong" democracy enabling the enjoyment of the Four Freedoms. These Freedoms, in turn, provide the foundations of human rights:

For there is nothing mysterious about the foundations of a healthy and strong democracy. The basic things expected by our people of their political and economic systems are simple. They are: Equality of opportunity for youth and for others. Jobs for those who can work. Security for those who need it. The ending of special privilege for the few. The preservation of civil liberties for all. The enjoyment of the fruits of scientific progress in a wider and constantly rising standard of living.

These are the simple, the basic things that must never be lost sight of in the turmoil and unbelievable complexity of our modern world. The inner and abiding strength of our economic and political systems is dependent upon the degree to which they fulfil these expectations. ... In the future days, which we seek to make secure, we look forward to a world founded upon four essential human freedoms. ${ }^{4}$

2 For this historical analysis, I have referred to two essential classics (Morsink and Glendon) and a more recent book which will surely soon become a new and essential classic, also written by one of the leading experts on the Right to Science (Schabas): Johannes Morsink, The Universal Declaration of Human Rights: Origins, Drafting and Intent, University of Pennsylvania Press, 1999; Mary Ann Glendon, A World Made New: Eleanor Roosevelt and the Universal Declaration of Human Rights, Random House, 2001; and William A. Schabas, The Universal Declaration of Human Rights. The travaux préparatoires, Cambridge University Press, 2013.

3 According to article 32 of the 1969 Vienna Convention on the Law of Treaties, "the preparatory work of the treaty and the circumstances of its conclusion" are not principle resources for interpreting the texts as regards their application, but are "supplementary means of interpretation" which can be used to "in order to confirm the meaning resulting from the application of article 31, or to determine the meaning when the interpretation according to article 31: (a) leaves the meaning ambiguous or obscure; or (b) leads to a result which is manifestly absurd or unreasonable." See for example LaGrand (Germany v. United States) [2001] ICJ Rep 466, paras. 104-109 and Julian Davis Mortenson, "Is the Vienna Convention Hostile to Drafting History?" (2013) Am. J. Int'l L. 107.

4 The Franklin D. Roosevelt Presidential Library and Museum: www.fdrlibrary.org/archives. 
The key aspect science played in Roosevelt's vision was confirmed in his famous letter to Vannevar Bush, ${ }^{5}$ the wartime head of US military research and development, in November 1944, in which Roosevelt imagined a better world after the war thanks to science and asked Bush for a specific plan to carry out this mission:

There is no reason why the lessons to be found (in times of war) cannot be profitably employed in times of peace.... What can be done ... to make known to the world as soon as possible the contributions which have been made during our war effort to scientific knowledge ... New frontiers of the mind are before us, and if they are pioneered with the same vision, boldness, and drive with which we have waged this war we can create a fuller and more fruitful employment and a fuller and more fruitful life. ${ }^{6}$

The President, however, died soon after and in the post-war period that followed two circumstances were to have serious influence on the debates regarding science. The first was the long-standing memory of the two atomic bombs dropped on Hiroshima and Nagasaki in August 1945, which placed science, its limits, its control, and the social responsibility of scientists at the forefront of many debates. ${ }^{7}$ The second was the new Cold War rivalry between the United States and the Soviet Union which, as we shall see, would have a profound impact on the issue of science and its role in the international arena.

Nevertheless, the role of science in the humanities was gaining traction, a concept that can clearly be seen in the evolution of the institution that we now know as the United Nations Educational, Scientific and Cultural Organization (UNESCO). The origins of UNESCO, as we know it, lie in a little-known debate which is however key to understanding the interplay between science and politics. UNESCO came into being on the initiative of the Conference of Allied Ministers of Education (CAME), following a proposal made by the United States to set up a United Nations Organisation for Educational and Cultural Reconstruction, and afterwards a United Nations Organisation for Education and Culture, UNECO. It was only later in a Conference in November 1945 that UNECO, entirely without any reference to science in its acronym, was revamped to create UNESCO. This conference, held in London and chaired by the British Minister for Education, Ms. Ellen Wilkinson, saw a group of scientists led by the biochemist Joseph Needham and the biologist Julian Huxley, both British, fight for the inclusion of science in the name and mandate of the new organization. Their commitment to the new organization would lead Needham to be installed as the Director of the Natural Sciences Section and Huxley to be inaugurated as the first Director General

5 On the Roosevelt-Bush relationship and its impact on the development of basic science see Jacques Mirenowicz, Sciences et démocratie: le couple impossible?, Ed. Charles Leopold Mayer, 2000.

6 The Scientific War Work of Linus C. Pauling website. Oregon State University. http://scarc .library.oregonstate.edu/coll/pauling/war/corr/sci13.006.4-roosevelt-bush-19441117.html.

7 For a history of scientists and the atomic bomb, see Diana Preston, Before the Fall-Out. From Marie Curie to Hiroshima, Walker \& Company, 2005. 
(in fact one of only two Director Generals in UNESCO's history to be a scientist, along with Federico Mayor Zaragoza, from Spain).

Encouraged by these two scientists, at the plenary session of the London Conference, Minister Wilkinson defended the position with the following very significant words:

Although the Organisation's original name does not mention science, the British delegation will present a proposal for the name to be Organisation for Education, Science and Culture. In these days, when we are all wondering, perhaps apprehensively, what the scientists will do to us next, it is important that they should be linked closely with the humanities and should feel that they have a responsibility to mankind. I do not believe that any scientists will have survived the world catastrophe, who will say that they are utterly uninterested in the social implications of their discoveries. ${ }^{8}$

The reason for briefly digressing into the creation history of UNESCO is to demonstrate the state of distrust ("what the scientists will do to us next") which pervaded the debate on the development of science when fully disconnected from values and aims. The role of science and technology in Nazi war crimes, and in the atomic bombs mentioned above, was still very present in their thoughts. ${ }^{9}$ Bearing in mind that the Nuremberg Doctor's Trial, ${ }^{10}$ with its 140 days of gruesome and horrendous evidence, was held during 1947, and that seven defendants found guilty were given the death penalty and hanged in June 1948, that is, right in the middle of the negotiation process for the Declaration, we can appreciate René Cassin's observation that this trial "influenced the debate on how or whether to connect human rights and science in the Universal Declaration."

Nevertheless, despite current affairs and developments, UNESCO's Constitution puts science at the service of other objectives (peace and security) and does not treat it as a purpose in itself: ${ }^{12}$

The purpose of the Organization is to contribute to peace and security by promoting collaboration among the nations through education, science and culture in order to

8 C. Atlee, E. Wilkinson, J. T. Bodet, R. Cassin (1985) The Life of the Mind. UNESCO Courier Oct: $8-9$.

9 It is interesting how for many authors the experience of a political and moral catastrophe was in fact the central prior condition not only for the creation of this article 27 but for the entire Declaration. Hence one cannot comprehend either the fact, structure, or the dynamic of the expansion of human rights after 1945 without interpreting it as a result of the experience of a political and moral catastrophe. Christoph Menke and Arnd Pollmann, Philosophie der Menschenrechte, Junius Verlag GMBH, 2017.

10 United States of America v. Karl Brandt et al. Nov. 21, 1946-Aug. 20, 1947, Accession Number: 1995. A.o970, RG Number: RG-30.001M (https://collections.ushmm.org/search/catalog/irn504191).

${ }^{11}$ Professor Richard Pierre Claude. Science in the Service of Human Rights. An Introductory Class for Science, Technology and Public Health. Princeton University Syllabus, 2002.

12 See the same idea in Fernando Valderrama, Historia de la UNESCO. UNESCO Reference Works. UNESCO Publications, Paris, 1995: "for UNESCO, education, science and culture are not purposes in themselves but rather means and tools for a spiritual enterprise and a moral conduct or effort. The final objective, declared in its Constitution, is peace based on respect for human rights," p. 29. 
further universal respect for justice, for the rule of law and for the human rights and fundamental freedoms which are affirmed for the peoples of the world, without distinction of race, sex, language or religion, by the Charter of the United Nations.

In this context, the Universal Declaration of Human Rights started out as a succession of working drafts over one and a half years. The first draft was prepared by the Canadian jurist John Peters Humphrey, who had been appointed the first Director of the United Nations Division of Human Rights. This draft is a very complete list of the rights which had been recorded in other declarations and reference texts. It was then rearranged and converted into a more consistent draft by the French jurist René Cassin. That draft had to then pass the drafting Committee and the sessions of the Human Rights Commission, before being approved by the United Nations Economic and Social Council (ECOSOC) and finally, on December 10, 1948, by the General Assembly in a session at the Palais Chaillot in Paris, leading to the Universal Declaration of Human Rights as we know it today.

Humphrey's first draft already included a Right to Science under the same article as a Right to Culture and to the Arts. According to René Cassin ${ }^{13}$ the article was included on request from cultural organizations, including UNESCO, ${ }^{14}$ which was represented at this time before the Commission on Human Rights by Jacques L. Havet. Already in this first version, we find that the choice of wording of the text is an important matter to consider.

In Humphrey's draft, the right is formulated as the right "to share in the benefits of science." This formulation appears to have been inspired by the Inter-American Juridical Committee for the American Declaration of the Rights and Duties of Man, ${ }^{15}$ as the Chilean delegation was keen to point out. ${ }^{16}$ This Declaration had been approved in Bogotá a few months before the Universal Declaration and it stated in its article XIII that "[e]very person has the right to take part in the cultural life of the community, to enjoy the arts, and to participate in the benefits that result from intellectual progress, especially scientific discoveries."

13 Morsink, p. 218.

14 On the UNESCO's intellectual contribution to the drafting of the Universal Declaration, see UNESCO/PHS/3(rev) Paris, July 25, 1948, with contributions by J. Maritain, M. Gandhi, E. H. Carr, B. Croce, R. P. Teilhard de Chardin, A. Huxley and two specific papers on scientific matters: "Rights and Duties Concerning Creative Expression, in particular in Science," by J. M. Burgers, and "Science and the Rights of Man," by W. A. Noyes.

15 Richard Pierre Claude looks for the origin of that contribution in the Inter-American Conference on the Problems on War and Peace, Mexico, 1945 ( Richard Pierre Claude, "Scientists' Rights and the Human Right to the Benefits of Science" in Audrey Chapman and Sage Russel, Core Obligations: Building a Framework for Economic, Social and Cultural Rights, Intersentia, 2002. p. 250)

16 Mikel Mancisidor, "El Derecho Humano a la Ciencia”, Anuario de Derechos Humanos. Universidad de Chile, 2017 . 


\subsection{DEBATE ON THE PURPOSE OF SCIENCE IN THE DECLARATION}

The end goal of science is and has long been a topic of perennial debate. As such, it should come as no surprise that this debate took on some importance during the negotiation of the Declaration in the political context of the Cold War. The debate started during the first rounds of drafting and discussion when the Soviet delegation, led by Alexei Pavlov, nephew of the well-known Russian scientist Ivan Pavlov, proposed a new text to the effect that this right should protect and promote certain objectives. The proposal stated that: "the development of science must serve the interest of progress and democracy and the cause of international peace and cooperation."

The proposal was reasonable enough on its face given that, as the Soviet delegation argued, the preceding article in the Declaration on the Right to Education had been given a new second paragraph on the objectives of education. In its final formulation, article 26 states:

26. 1. Everyone has the right to education.... 2. Education shall be directed to the full development of the human personality and to the strengthening of respect for human rights and fundamental freedoms. It shall promote understanding, tolerance and friendship among all nations, racial or religious groups, and shall further the activities of the United Nations for the maintenance of peace.

If it had been considered appropriate under the Right to Education to refer to the objectives or aims of education (human development, human rights, understanding, tolerance, peace, and so on), the Soviet proposal of including the objectives of science to be protected and promoted by the Right to Science appeared logical on the same grounds. However, in the end, the three ideas contained in the proposal (progress, democracy, and peace and international cooperation) were voted on separately and all three were rejected. Some States considered that science, and therefore the Right to Science, should not be subject to any purpose, however noble, given that its aim could only be to seek the truth. ${ }^{17}$

The Ecuadorian delegate explained his vote during the debates on the Declaration by saying that "science should serve the interests of life rather than death, of peace rather than war." The Soviet proposal seemed reasonable enough,

17 See the Belgian position ("the USSR amendment was an attempt to assign science a political mission. While he (the Belgian delegate) wanted science to serve the cause of peace and co-operation among nations, he thought it was not for the declaration of human rights to define its role. In any case, if it had to be done it would have been better to say that the aim of science was the search for truth") or in even stronger terms by the Cuban stance (the delegation "was convinced that science should remain entirely free and that the State should not interfere at any stage in scientific or literary creation. On the contrary, it was democracy which should be placed at the service of science, the latter itself the servant of truth. Those who had faith in man could not fear truth. That was the spirit underlying the declaration of human rights.") Cassin was concerned about the possibility of the idea being "invoked to justify the harnessing of science to political ends". And Chile feared that "it might in practice lead to the control of scientific research for political ends". Citations taken from Morsink. 
certainly, except when considered under the perverse Cold War logic dominant at the time. ${ }^{18}$ The fact was that other delegations distrusted the concept of democracy being defended by the USSR and its satellites. Eleanor Roosevelt, for example, feared a right "applied to abstract ideas for which no uniform interpretation existed. It seemed dangerous to adopt a text which could be interpreted as a pretext for the enslavement of science. The US delegation would under no circumstances agree that science should be placed at the service of politics. Yet that might be the practical effect of the USSR amendment."19 Similarly, the British delegation added that "unfortunately, the conception of democracy and of progress did not seem to be the same everywhere. The word 'democracy' could be interpreted in many ways ... science should not be at the service of an ideology." ${ }^{20}$

The Soviet delegation warned about the danger of a "science subservient to militarism and where intellectual forces were concentrated on producing a terrible weapon"21 twelve years before Eisenhower denounced:

the acquisition of unwarranted influence, whether sought or unsought, by the military industrial complex. The potential for the disastrous rise of misplaced power exists and will persist... Akin to, and largely responsible for the sweeping changes in our industrial-military posture, has been the technological revolution during recent decades.

In this revolution, research has become central; it also becomes more formalized, complex, and costly ... a government contract becomes virtually a substitute for intellectual curiosity ... Yet, in holding scientific research and discovery in respect, as we should, we must also be alert to the equal and opposite danger that public policy could itself become the captive of a scientific technological elite. ${ }^{22}$

A neutral observer might have considered the Soviet concern as being along the right lines, or even seen it as visionary, although, with the benefit of historical hindsight, the reluctance of the other countries might also appear justified, given that they were faced with Stalin's militarized Soviet Union at the beginning of the Cold War.

As we now know, the final formulation, for good or ill, rightly or wrongly, avoided references to the purposes of the Right to Science, or of science itself, beyond enjoying the "benefits which derive from it."

18 "The United Nations General Assembly adopted the Universal Declaration of Human Rights ... in the midst of an especially bitter phase of the Cold War." Dr John F. Sears, available at www .fdrlibrary.org/documents/356632/390886/sears.pdf/czooe13o-b6e6-458o-8bfi-o7b72195b370.

19 Morsink considers this position "spurious" although this author is not so sure. The author does however go on to recall that once the proposal had been rejected Eleanor Roosevelt generously declared that "during the war science in the United States had been placed at the service of Government and it might be recalled that all the allies, including the USSR, had profited therefrom." (pp. 62-63)

20 Morsink, p. 63 .

21 Morsink, p. 62.

22 Public Papers of the Presidents of the United States Dwight Eisenhower, Published by the National Archives of the United States, 1961. Doc. N. 421, pp. 1035-1040. 


\subsection{PRIMARY OBJECTS OF THE RIGHT ACCORDING \\ TO THE DECLARATION}

At one stage of the Declaration negotiation process the formulation of the right was modified from the initial version based "on the benefits that result from scientific discoveries" to the wider idea of the right to "share in scientific advancement." This significant change was approved on a proposal from China, based, according to the delegate Peng Chun Chang, on the authority of Francis Bacon. ${ }^{23} 2425$

This change and the loss of the word "benefits" did not last long and it was soon restored. ${ }^{26}$ The Soviet delegation had already voiced its support for the idea of "benefits": "the benefits of science were not the property of a chosen few, but the heritage of mankind ... that the task of science was to work for the advancement of peaceful aims and to make human life better." ${ }^{\text {27 }}$ However, the word was recovered on submission from Cuba with the argument that "not everyone was sufficiently gifted to play a part in scientific advancement" and that what was needed was for the text to state that everyone has the right "to share in the benefits that result from scientific advancement." ${ }^{28}$ Chile supported the Cuban proposal emphasizing that, as the Inter-American Juridical Committee had proposed, the key concept was the idea of "benefits."

To this both the Chinese and Saudi Arabian delegation added that even if one does not have the capacities to contribute to scientific knowledge, we all nevertheless possess the capacity for certain enjoyments of science beyond just its direct, material benefits. ${ }^{29}$

In the end, however, Cassin agreed with the Cuban vision and declared that "even if all persons could not play an equal part in scientific progress, they should indisputably be able to participate in the benefits derived from it." ${ }^{\circ}$

23 William A. Schabas "Study of the Right to Enjoy the Benefits of the Scientific and Technological Progress and its Applications" in Yvonne Donders and Vladimir Volodin (eds.) Human Rights in Education, Science and Culture, UNESCO Ashgate, 2007. p. 276; and Morsink, p. 219.

24 It is curious that we cite here Dr. P. C. Chang as if his great contribution was based on the authority of a Western classic, when "Dr. Chang was one of the few members of the Commission who consistently reminded his colleagues that a Universal Declaration had to incorporate philosophical systems other than those of the West, and he himself frequently cited Confucian principles to inform the discussion. Humphrey credits him with using his mastery of Confucian philosophy to find compromise language at particularly difficult points." M. Glen Johnson and Janusz Symonides, (eds.), The Universal Declaration of Human Rights: A History of its Creation and Implementation 1948-1998. Preface by Federico Mayor Zaragoza. UNESCO, 1998. p. 22.

25 The importance of Chang's contribution was seen differently to how it is seen here by Richard Pierre Claude: "the elitist tone of the original article, appearing only to protect scientists, was thus overcome by Mr Chang's proposal that everyone has the right not only to share in the advancement of science (scientists and students of science) but also to share in their benefits (the general public)" (Claude, “Scientists ..." pp. 253-254).

26 On which see generally Morsink and Schabas.

27 Morsink, p. 219 .

28 Morsink, p. 219.

29 Morsink, p. 219.

30 Morsink, p. 219 
This back-and-forth exchange of ripostes nonetheless ended with the concept of the benefits of science being restored by consensus and added to, rather than substituted into, the Chinese text, which is more important than it may seem.

This historical debate helps explain the prevalence of the misapprehension that the scope of this right is limited to participating in "the benefits of science" which means, among other things, the ability to "be able to receive affordable medicine." ${ }^{11}$ One of this chapter's intentions is to provide a more comprehensive and ambitious interpretation of this key phrase than the mere idea of "[being] able to receive." The word "share" in the phrase "everyone has the right freely ... to share in scientific advancement and its benefits," may appear at first sight to be of a high level of generality, and as connoting less engagement or activity than the alternative phrases to "participate" or "take part." However, given the background above the phrase must in my judgment be taken to indicate an idea of action or agency, of active participation in an enterprise or endeavor, and must therefore be considered in this regard to have the same meaning as "participate" or "take part."

Against this statement one could argue that since article 27 opens with the expression "everyone has the right freely to participate in the cultural life of the community," that had the authors intended to use this same idea of active participation also in science, then they would have used the same word; however, this was not the case as "share in" was chosen instead, possibly precisely to reduce this association with action. However, the French and Spanish versions of the Declaration, which are equally valid, clearly opt for the idea I propose by including the words "participer" and "participar," which are without doubt identical synonyms of their French and Spanish counterparts, "prendre part" or "tomar parte," which are used to open the article.

If we examine international law criteria for interpreting identical texts in two or more languages, ${ }^{32}$ we see that "the text is equally authoritative in each language," that "[t]he terms of the treaty are presumed to have the same meaning in each authentic text" and that "when a comparison of the authentic texts discloses a difference of meaning ... the meaning which best reconciles the texts, having regard to the object and purpose of the treaty, shall be adopted." I propose without doubt that we should opt for an interpretation of "to share in" that is synonymous with "to participate in" or "to take part in" through which we achieve the equivalence of meanings between language versions necessary to "reconcile the texts."

Further support for this position may be derived from General Comment No. 21 on the Right to Participate in Cultural Life, and the work of the Committee for Economic, Social and Cultural Rights (CESCR), which have previously analyzed

31 Here I use an expression borrowed from Morsink, p. 219.

32 Article 33 of the Vienna Convention on the Law of Treaties states that when a treaty has been authenticated in two or more languages, the text is equally authoritative in each language, unless the treaty provides or the parties agree that, in case of divergence, a particular text shall prevail. The terms of the treaty are presumed to have the same meaning in each authentic text. 
the meaning and scope of the term "to participate" or "to take part" in and indicated that "they have the same meaning" and include both "access" and "contribution." 33 The same idea applies to interpreting the Right to Science. ${ }^{34}$

Although this reflection delves deeply into semantics, this analysis is essential to framing our vision of a right which goes beyond "benefit from" and advocates broader concepts of "participation in;" a right which includes participation in scientific creation ${ }^{35}$ (citizen science), ${ }^{36}$ and participation in scientific policy, ${ }^{37}$ among other things. The recent approval of the General Comment No. 25 by $\mathrm{CESCR}^{3}$ provides enough guiding elements to revisit this question with new tools.

\subsection{A BRIEF CONSIDERATION OF THE NAME OF THE RIGHT}

Up to this point we have referred to this right as the Right to Science, which might appear to some as lacking in technical precision. Many authors outright reject this framing. It does however merit further consideration.

We could refer to this right in the terms of the Universal Declaration as the "right to share in scientific advancement and its benefits" (RSSAB) or in terms of the ICESCR as the "right to enjoy the benefits of scientific progress and its applications" (REBSP), but it is clear these are both unwieldy and of limited usefulness as formulae if we wish to develop this right, disseminate it, and hope for its uptake

33 "15. There are, among others, three interrelated main components of the right to participate or take part in cultural life: (a) participation in, (b) access to, and (c) contribution to cultural life."

34 E/C.12/GC/21Committee on Economic, Social and Cultural Rights. Forty-third session. 2-20 November 2009. General comment No. 21: Right of everyone to take part in cultural life (art. 15, para. 1 (a), of the International Covenant on Economic, Social and Cultural Rights).

35 "Ground is being made in the idea that knowledge is a matter of all, work to which ... all citizens contribute. Little by little the capacity has been recognised of all human beings to participate in research, invent and do science, or at least judge some of its conclusions. At the beginning of the nineties organisations like the American Association for the Advancement of Science (AAAS) and UNESCO proclaimed the slogan 'science for all', which can be summarised as follows: not only science in the service of all, but science for all." (Daniel Innerarity, La democracia del conocimiento. Por una sociedad inteligente, Paidós, Barcelona, 2011. p. 130).

${ }^{36}$ "The idea of "civic science" (Alan Irving, Citizen Science: A Study of People, Expertise and Sustainable Government, London, Routledge. 1995) or of a "scientific citizen" (Frank Fisher, Citizens, Experts and Environment. The Politics of Local Knowledge, Durham NC, Duke University Press Books, 2000) refer to the current challenges regarding how to introduce nonscientific agents into the decision-making processes, how to take local knowledge and experience into consideration, how to report risk in a transparent manner or other similar democratisation requirements." (Innerarity, p. 114).

37 On participation in decision-making and its problems and solutions, with important ideas and interesting examples, see Daniel Lee Kleinman, "Democratization of Science and Technology" in Daniel Lee Kleinman (ed.), Science, Technology \& Democracy, State University of New York Press, 2000 .

$3^{8}$ E/C.12/GC/25, Committee on Economic, Social and Cultural Rights. Sixty-seventh Session, 30 April 2020. General comment No. 25 (2020) on science and economic, social and cultural rights (article 15 (1) (b), (2), (3) and (4) of the International Covenant on Economic, Social and Cultural Rights). 
and use by the broader society. General Comment No. 25 chooses to use another, more complete, wording which might still suffer some practical problems in the everyday, and certainly oral, usage: "the right to participate in and to enjoy the benefits of Scientific Progress and its Applications (RPEBSPA)."

Some may find in its abbreviated formulation, the Right to Science, opportunities for humor. For example, science is not accessed as of right but through effort and intellectual energy, which is clearly true (since Euclid we have known that "there is no Royal Road to geometry"). Yet, putting cynicism aside, the fact remains that when we speak about the Right to Health, ${ }^{39}$ technically what we are speaking about is the right to the "enjoyment of the highest attainable standard of physical and mental health," and not about a right to be healthy by decree. The same applies to the Right to Science. A simple name does not simplify or caricature a right's normative contents, but is instead intended to offer practical cognitive advantages facilitating familiarity with the concept and easing the cognitive burdens of its use. We are interested in a shorter, more manageable, and more easily popularized formulation than the RSSAB or the REBSP or RPEBSPA. Lea Shaver has suggested a very interesting name, the Right to Science and Culture, which includes the artistic, cultural, and scientific contents of article 27 of the Declaration. For Shaver, "[a]lthough 'science' and 'culture' are invoked separately in both UNESCO's name and the Article 27 text, there is no clear dividing line between these two fields .... This integrated approach is captured by my emphasis on the unifying concept of the "Right to science and culture."'40

There are substantial grounds for this unified approach to science and culture, not the least of which can be discerned from the points this chapter has already made above and in chapters by several other distinguished commentators on the right to science contained within this volume. That said, for practical reasons, and to most effectively develop the contents of science and culture, it is arguably most appropriate to continue, at least for now, working in pursuit of an autonomous Right to Science within the field of cultural rights. Shaver's proposal still appears to me to be an attractive option full of suggestive possibilities.

Another short-form name for the right, the "right to access to knowledge," has been suggested, backed by the authority of B. Boutros-Ghali, ${ }^{41}$ although it could be said that this formulation only refers to some of the possible normative contents of the Right to Science. ${ }^{42}$ The Information Society Project at Yale

39 I am grateful for the example given at public lectures by Lea Shaver and Jessica Wyndham.

$4 \circ$ Lea Shaver, "The Right to Science and Culture," Wisconsin Law Review 2010, no. 1, 121-184, at p. 156.

41 B. Boutros-Ghali, "The Right to Culture and the Universal Declaration of Human Rights" at the UNESCO's Meeting of Experts on Cultural Rights as Human Rights, Paris, 1968. Subsequently published under the title Cultural Rights as Human Rights, UNESCO, Paris, 1970. Cited by Shaver, p. 153. The expression "right to knowledge" did at least have a precedent in the Declaration of Principles of International Cultural Cooperation de 1966 (Shaver, p. 156).

42 The conceptual idea put forward by Boutros-Ghali back in 1968 might now be considered somewhat limited: “(Art. 27) assumes firstly that the individual has attained a 'standard of living adequate' ... For, if the individual has not reached this standard because he is undernourished or even starving, 
Law School has opted for solid arguments based on the ICESCR for the same formulation of a "right of access to knowledge" or more briefly still, "the right to knowledge." ${ }^{43}$ Here, the more flexible and practical "Right to Science" is advanced as the most appropriate, encouraged by the fact that it has already been accepted by a considerable number of authors, ${ }^{44}$ scientific and academic associations, social organizations, the first Special Rapporteur in the Field of Cultural Rights, Farida Shaheed, ${ }^{45}$ UNESCO,${ }^{46}$ and some countries. ${ }^{47}$

Some may say that what is gained in flexibility is lost in rigor when considered against the REBSP, but it could be said that the short formulation is at once more ambitious because it contains all the contents of a right to actively access science beyond merely passively participating in its benefits. It is this framework that is defended in this chapter. What we shorten in title we increase in contents.

The commitment to an autonomous and differentiated Right to Science must not prevent it from being read together and in harmony with other human rights and in particular with the cultural rights of which it forms part,,$^{4}$ and with which it is

because he has no decent lodging or lacks the possibility of receiving the most elementary medical attention, it is evident that he will have neither the desire nor the possibility of taking part in the cultural life of his community and there can be no question of his enjoying the arts and literature, still less of participating in scientific advancement." Shaver, p. 73.

43 "Article 15 contains three provisions addressing (a) cultural participation, (b) access to the benefits of science and technology, and (c) protection of authorship. A careful reading, however, makes clear that these must be understood as three aspects of a single right, as the text continues: 'the steps to be taken by the States Parties to the present Covenant to achieve the full realization of this right shall include those necessary for the conservation, the development and the diffusion of science and culture.' The Covenant's use of the singular noun 'this right' indicates that the $15(1)(\mathrm{a}-\mathrm{c})$ provisions are intended as three interrelated aspects of a single human right: the right of everyone to participate in the advancement and share in the benefits of human knowledge - both scientific and cultural. This scope is best captured by the phrase 'the right of access to knowledge,' or more briefly still, 'the right to knowledge." www.yaleisp.org/sites/default/files/publications/articleı5.pdf.

44 S. Porsdam Mann, V. J. Bradley, M. F. Chou, G. Church, M. Mann, C. Mitchell, Y. Donders and H. Porsdam, "On the human right to enjoy the benefits of science and its applications" Proceedings of the National Academies of Science, October 23, 2018, 115 (43) 10820-10823; S. Porsdam Mann, Y. Donders and H. Porsdam, "Sleeping beauty: the Human Right to Science," Human Rights Quarterly, Volume 42, Number 2, May 2020, 332-356.

45 A/HRC/20/26, Human Rights Council, Twentieth session, 14 May 2012, Report of the Special Rapporteur in the field of cultural rights, Farida Shaheed: The right to enjoy the benefits of scientific progress and its applications, "this right, referred herein as the right to science," para. 3.

$4^{6}$ https://en.unesco.org/commemorations/worldsciencedayzor8.

47 XXVI Cumbre Iberoamericana de Jefes de Estado y de Gobierno. Declaración Final. Guatemala, 16 November, 2018. Para. 45, www.segib.org/wp-content/uploads/oo.1.-DECLARACION-DE-LAXXVI-CUMBRE-GUATEMALA_VF_E.pdf.

$4^{8}$ "Five human Rights are understood - according to Elsa Stamapopulou - as cultural rights under International Law: 1. The Right to Education; 2. The Right to Participate in Cultural Life; 3. The Right to Enjoy the Benefits of Scientific Progress and its Applications; 4. The Right to Benefit from the protection of the moral and material interest resulting from any scientific, cultural or artistic production of which the person is the author, and, 5. the freedom for scientific research and creative activity." Elsa Stamatopoulou, Cultural Rights in International Law. Article 27 of the Universal Declaration of Human Rights and Beyond, Matrinus Nijhoff, 2007. 
"inherently interlinked"49 as the Special Rapporteur on Cultural Rights rightly says, or as the Information Society Project argues in favor of the right of access to knowledge.

It seems that over time, the use of the expression "Right to Science" will become a familiar shorthand, making this type of nominalist explanation no longer necessary, and it will be used for ease of exposition in the same way we speak about the Right to Health, the Right to Work, or the Right to Housing, which are at least as problematic as the Right to Science when it comes to the gulf existing between a simplistic reading of their formulation and their real contents.

\subsection{THE RIGHT TO SCIENCE AS A CULTURAL RIGHT}

The importance of science for the enjoyment of other human rights and for sustainable human development is thankfully beyond doubt. Thousands of pages have been written on science's importance for the challenges facing our societies and our planet, and plenty more on science's importance for our wellbeing and for the opportunities and possibilities currently in our hands.

Thanks to scientific and technological advancement we have managed, in global terms, to double life expectancy, vanquish much suffering and disease, and we are also able to produce sufficient food to feed the world (the fact that we do not have sufficient institutional, economic, political, or ethical resources to make the most of this capacity is altogether another matter). Bertrand Russell once said that "science can confer two kinds of benefits: it can diminish bad things, and it can increase good things." ${ }^{\circ}$ Nowadays, we have access to information and knowledge which was previously unimaginable, at a speed and price which surprises us every day. All of this provides us with the opportunity to be free, to choose, to learn, to investigate, ... to develop ourselves as persons and as communities, because "the knowledge society has more possibilities for personal freedom than all previous social forms." ${ }^{51}$

It is true that this development has brought with it new problems that were previously unknown: new diseases; novel risks and threats like the loss of biodiversity, climate change, contamination; how to apportion and manage control over the continually expanding mass of useful information; loss of privacy; the dilemmas of bioethics; and many others. It is not suggested that science alone can solve these challenges; it is certain, however, that without science they cannot be successfully and responsibly tackled. Science is not therefore ultimately responsible for these challenges, but it is an essential element in meeting them. The response to these

49 Farida Shaheed A/HRC/20/26 (n. 45): "the Special Rapporteur views these rights inherently interlinked, since both relate to the pursuit of knowledge and understanding and to human creativity in a constantly changing world" (para. 3) and "the rights to science and culture are interlinked" (para. 16).

50 Bertrand Russell, The Impact of Science on Society, London, 1952. p. 104.

${ }^{51}$ Innerarity, p. 73. 
challenges must be social, political, economic, ethical, ${ }^{2}$ and also scientific, because the response must be based on scientific knowledge on our side. ${ }^{53}$

Science is directly related to various rights up to the point where they have common contents. Take, for example, its interconnections with the Right to Education: education is necessary for the performance of science, and science is essential to any proper education from primary school level and beyond. Consider the Right to Health: the right to enjoy the highest possible level of physical and mental health relies in large part for its fulfilment on the right to benefit from the advancement of scientific progress, and especially its applications. With respect to the Right to Food or the Right to Water and Sanitation, it is clear that science and technology must be allies for progress in the universalization of the enjoyment of those basic needs. As for Rights of Association, Information, and Expression, these are all essential requirements for the smooth and efficient workings of the scientific community. The UNESCO representative at the Commission on Human Rights, Jacques L. Havet, pronounced very clearly on this matter at the Seventh Session: "The right of everyone to enjoy his share of the benefits of science was to a great extent the determining factor for the exercise by mankind as a whole of many other rights." 54

The relationship between gender equality (or the principle of nondiscrimination on the grounds of gender) and science is also important. Scientific and technological advancement favor equality. Advancements ranging from progress in sexual and reproductive health, to the facilities provided by technology in areas traditionally (and in many places still currently) identified with women, through to scientific evidence of the persistence of the wage gap and continued implicit biases against women in some professions, have been of great practical usefulness in the fight for access by women to other previously taboo, or even vetoed, social and labor areas. Equality is also one of the contents of the Right to science which makes it crucial given there is still considerable imbalance in access to education by women in general and above all to professional technical scientific work in particular. This is so even in countries which are considered advanced in this issue. Inequality also leads to a loss of talent and capacity for science itself, which, given the reflections above on the interconnections between science and several human rights, must necessarily compound to the greater loss of humanity.

52 "The increasing gap opening between technology and human needs can only be reduced by turning to ethics" states the eminent physicist Freeman Dyson in his delightful collection of learned articles The Scientist as a Rebel, New York Review Books, 2006.

53 "Des choix sont à faire, les plus démocratiques possible, et les plus éclairés aussi. Mais une chose est sûre: nous ne préserverons pas la biodiversité avec la biologie de Pline l'Ancien, ni ne stabiliserons le climat avec la physique d'Aristote.” The humorous ending to the fine book by Étienne Klein, Allonsnous liquider la science? Galilée et les Indiens, Flammarion, 2008. p. 120.

54 Cited by William A. Schabas : "Study of the Right to Enjoy the Benefits of Scientific and Technological Progress and Its Applications" in Yvonne Donders and Vladimir Volodin, Human Rights in Education, Science and Culture. Legal Development and Challenges, UNESCO Publishing/Ashgate, Paris, 2007. p. 281. 
Finally, the relationship between democracy and science is also important. Experience has shown that science flourishes more easily in settings with freedom and participation. In turn, science becomes a force for democracy by providing citizens with the knowledge needed to act responsibly in the political debate, and by providing better technological tools for participation. ${ }^{55}$ The relationship between science and human development, the Sustainable Development Goals, and a great many other issues could be easily developed. Not much of value, though, would be added to the debate that has not been covered above. What should be highlighted is that intentional emphasis has been placed on the idea of an interrelationship or interdependence between science and other rights and interests. We must not frame a vision of science solely as an instrument for other more valuable objectives, but rather as an interaction between human assets.

This is because the need for a Right to Science is often justified by reference to science's importance for the enjoyment of other rights and this is exactly the idea I want to challenge: evidently not because it is false, but because it is insufficient for the basis of science as a human right. If science's role is purely instrumental, for the attainment of other rights, the right to science would in the best of cases be a derivative, instrumental or secondary right. I advance the argument that this right should go much further, and indeed has its own objectives and inherent value which justify it standing alone as a separate human right. In this sense, scientific knowledge makes us more human, it allows us to know ourselves and our environment better, to make better individual and collective decisions, and to enjoy life and its beauty more fully.

There is furthermore a logical, internal reason derived from the UDHR which should be stressed here: the Right to Science is contained within provisions dedicated to cultural rights, in the same category as the right to "participate in the cultural life" and the right to "enjoy the arts." There is no argument that suggests participation in cultural life or the arts should be justified as human rights by reference to their service to other ulterior or higher purposes, and they are accepted as objectives in themselves. Nor is anyone asked to explain the use of poetry, dance, or music to defend their right to create and enjoy them. The same should be said of science: its relationship to creativity, aesthetic and intellectual enjoyment, and

55 The scientist and ex-Director General of UNESCO, Federico Mayor Zaragoza, often insists on the importance of "the possibility of remote participation thanks to the information and communication technology" ("Invest in the future." El País, 21 August 2012). "Technology to disseminate values, to realise the basic principle of human rights: equal dignity for all, without exceptions. Technology to disseminate the risk, to avoid fear, dogmatism, fanaticism, extremism ... Technology to create a global awareness which allows is to better appreciate what we have and the precarious situation of others. Technology to see the invisible and thereby contribute towards making what it impossible today possible in the future. Technology to mobilise, to arouse the dormant, the numb, those who are tired of waiting, the silenced and the silent, so that they can dream again, so that they spare no efforts in showing that the radical changes which are so desired are, in fact, feasible." "Women, technology and democracy for social change." http://federicomayor.blogspot.com.es/2012/10/mujer-tecnologia -y-democracia-para-el.html. 
human curiosity and understanding, should suffice in order to justify it as a human right. ${ }^{5}$ We might say that the right "to share in scientific advancement" is an objective in itself, additional to "shar[ing] in ... its benefits," where the latter of these expressions is concerned mainly with the useful effects of science on the enjoyment of other rights. More colloquially, we might say that people have a right to science for the same reason as they have a right to literature (read and write), because they are objectives in themselves, universally realizable assets, a human necessity; but that perhaps they have the right to benefit from science, in principle, because they have the right to health or to food. Had the intention been otherwise, the Right to Science would be more of an instrument of economic and social rights, and its logical position would be amongst these. It has, however, right from the beginning, been set amongst the cultural rights because, as stated by a wellknown scientist and commentator, "science is culture in capital letters."

Science is a basic human necessity and, as already stated, not only due to its effects on other rights but as a necessity in itself. Science makes us human, just like literature or music, or history or linguistic diversity, and this is why it is a necessity associated with the concept of dignity.

\subsection{FINAL CONSIDERATIONS}

This chapter examined the debates and dilemmas that led to the creation of a right that included elements both of participation in and the enjoyment of the benefits of science. It is a right that has profound political implications. It was always a means to achieve other goods and goals, but it was above all a cultural right; that is to say, a good in itself. As a book chapter it was finalized in the middle of the COVID-19 confinement. The current relevance of the right to science is therefore greater than ever..$^{58}$ It is a human right that adds key dimensions, some of them previously undervalued, to the debate around science and human rights, from access to knowledge to citizen participation, from transparency to quality, and from promoting the role of women and minorities in science to balancing intellectual property and facilitating universal access to its applications. It includes the need for the promotion of research, development \& innovation, public funding and, in conclusion, it puts science at the service of citizens and the world, through international scientific cooperation. There are few challenges more pressing than to revisit the spirit of article 27 of the 1948 Universal Declaration of Human Rights, and to ensure its revival and enhance its influence in the contemporary era.

$5^{6}$ Due to its different subject matter, the right to science will have different practical implications and will be handled differently to the rights to participate in culture and the arts, but here we are only talking about the basis as a human right.

57 Interview with Juan Ignacio Perez Iglesias. DEIA, 03.11.13 www.deia.com/2013/11/oz/bizkaia/bilbao/ juan-ignacio-perez-la-ciencia-es-cultura-con-mayusculas.

$5^{8}$ See Stjepan Oreskovic and Sebastian Porsdam Mann's Chapter 10, "Science in the times of SARS$\mathrm{CoV}-2$," for more on this topic. 